\title{
The mother and the young child: Who programs whom
}

\begin{tabular}{c} 
Sorin Buzinschi \\
Faculty of Medicine, "Transilvania" University, Brasov, Romania \\
\hline
\end{tabular}

\begin{abstract}
Intrauterine life is regulated by an epigenetic programme which adapts fetal life to the current and presumed conditions. The fetal programming determined by maternal nutritional disorders is at the origin of some metabolic and cardiovascular diseases of childhood and adult life. The maternal programming guides the child's immunity, circadian rhythm, and stress response. The maternal and paternal imprinted genes exert a contradictory action upon fetal development (the war of the sexes). In turn, the fetus programs the maternal physiology through placental hormones and the cell transfer in the maternal organism (feto-maternal microchimerism).
\end{abstract}

Keywords: maternal fetal programming, metabolism, immunity, circadian rhythm, stress, parental conflict, feto-maternal programming

\section{INTRODUCTION}

In the model centered on the genetic concept, parental influence on the development of the offsprings was subordinated to a predefined genetic program (1). The accumulation of clinical and experimental studies has highlighted that in fact genes express themselves differently according to the environment. One of the most shocking medical hyposthesis at the end of the $20^{\text {th }}$ century was the connection between the prematurity/low birth weight and the chronic pathology of the adult age (2-4). Considering that in terms of life cycle the most important stage of natural selection takes place prenatally, numerous studies have proven that there is a connection between nutrition, the mother's life conditions and the intrauterine and subsequent development of the child, these being at the origin of some somatic and psychic disorders. In other words, the intrauterine life is part of a rigorous developing program in which no detail is insignificant. All of these adaptations are made possible by changes in gene expression without changes in DNA sequences, that is by epigenetic mechanisms. The epigenetic inheritance regards the transmission of some epigenetic markers to the offsprings (1), the phenotype being the result of the interference of genetic factors and those originated in the environment (epigenetic).
TABLE 1. Critical periods in prenatal development

\begin{tabular}{|l|l|l|}
\hline Organs/systems & $\begin{array}{l}\text { Maximum } \\
\text { sensitivity }\end{array}$ & $\begin{array}{l}\text { Development } \\
\text { until }\end{array}$ \\
\hline CNS & $4-8$ weeks & Post-natal - adult \\
\hline Heart & $5-9$ weeks & 12 weeks \\
\hline Limbs & $6-10$ weeks & 12 weeks \\
\hline Eyes & $6-10$ weeks & Term \\
\hline Auditory system & $6-11$ weeks & 13 weeks \\
\hline Pancreas (insulin secretion) & $7-?$ weeks & Term \\
\hline Kidneys & $8-32(34)$ weeks & Term \\
\hline
\end{tabular}

In the light of the collected data, fetal programming is considered to be at the origin of the events that take place during conception, intrauterine life, childhood, and adulthood, being connected by the epigenetic background. Thus, certain diseases which occurred in the first part of life become predictors of adult pathology. Some studies which became "classic" followed the over time evolution of some subjects exposed to some nutritional restrictions during intrauterine life. During the famine in the Netherlands (1944-1945), during the Second World War, the medium food intake ranged between 300 and 600 calories per day. The children born during this time manifested after 50 years a structure of pathology which was linked to the period of damaged pregnancy (7). 
TABLE 2. A synthesis of types of pathology in adults aged over 50 , according to the period of maternal nutritional deprivation in the Netherlands, 1944-1945 (7)

\begin{tabular}{|l|l|l|}
\hline First trimester & Second trimester & Third trimester \\
\hline Glucose intolerance & Glucose intolerance & Glucose \\
Cardiovascular disease & Pulmonary disease & intolerance \\
Arterial hypertension & Renal disease & Cardiovascular \\
(AH) & & disease \\
Dyslipidemia & & \\
Obesity & & \\
Emotional disorders & & \\
\hline
\end{tabular}

The trend of birth weight increase linked to the high rate of overweight or obese women was noticed in various countries during the last decades. Maternal chronic hyperglycemia is responsible for the accumulation of an abundant adipose tissue in newborns. Paradoxically, the consequences of fetal macrosomia (birth weight of over 4,000-4,500 g) are similar to those of children with low birth weight in terms of the occurrence of diabetes mellitus (DM) during adolescence or adulthood (8). A study compared the weight of children born before the bariatric surgery for obesity (macrosomia of $34.8 \%$ ) with that of a group of women after the same type of surgery (macrosomia of 7.7\%) (9). The data suggest the intergenerational transmission of the decrease in glucose tolerance and of obesity of nongenetic origin. Numerous clinical and experimental data support the epigenetic involvement in the appearance of obesity, of NIDDM, AH, and other diseases.

\section{MATERNAL PROGRAMMING OF THE CHILD'S IMMUNITY}

Except for its nutritious role, maternal milk plays other major biological roles: the formation and modulation of the immunity, the live cell transfer through maternal milk, the microflora formation of the newborn and infant. The capacity of maternal milk to develop and modulate neonatal and later immunity is based on the transmission of an enormous quantity of information expressed through different molecules (cytokines, interleukins, defensins, hormones, growth factors, immunoglobulins etc.), cells and microorganisms. The process of transmission of the maternal antibodies to the neonatal naïve immune system is initiated transplacentally under the action of fetal $\mathrm{Fc}$ receptors. Immunoglobulins of the type $\operatorname{IgG}, \operatorname{IgM}$ and IgA have been identified in colostrum and mature milk. The persistence of maternal antibodies in the nursling's circulation continues until the age of 9 months and is dependent on the beginning of their active production (10). Abundantly represented in the maternal milk, IgA plays an important role; as secretory IgA, it connects to the mucus layer of the epithelial intestinal cells, forming a barrier against the ag- gressive pathogens, before the contact with the epithelial cells (11). As a response to its own intestinal antigens, the maternal immune system produces IgA antibodies; the immune information is transferred to the mammary plasmocytes, which, in turn, take over the production of the same type of antibodies (the enteromammary system). This results in the bacterial intestinal colonization of the newborn with a commensal flora similar to that of the maternal intestine and the limitation of pathogen proliferation. The effect of transferring maternal antibodies to the newborns and infants manifests only for a relatively short period but it leads to the irreversible programming of the immune repertoire, suggesting that, in some cases, the maternal antibodies may influence the immune function along many generations (12). In the maternal milk there are live bacteria which come from the mammary ducts and areola, but they are partially intrinsic components of the milk (13). Observations that maternal milk is not sterile, even when it is aseptically collected, support the idea that this is a natural bacterial colonizing source of the neonatal intestine (12). The origin of the bacteria identified in milk is found in the maternal intestine; the observation is backed up by the finding that identical bacterial DNA fragments can be identified in the maternal stool, blood, milk, and in the nurslings' stools (10). The transfer of the viable bacteria or their genetic material is ensured by maternal mononuclear cells both during the pregnancy and after (15). The population of the gastrointestinal tract begins before birth as the fetus ingests amniotic fluid which contains microbial germs (14). Even if the composition of the microbiota changes with age, the microbial flora acquired from the mother at birth and during the natural feeding will influence the development of intestinal microbial environment in the long run. The immune programming of the intestine through lactation is also assumed by the transfer of live and active leukocytes, among which most of them are macrophage and polymorphonuclear. The population of lymphocytes transferred to the nursling consists of Ly T motile and interactive, involved in the active transfer of immunity $(16,17)$; among these, Foxp3 (Treg) play an important role in constituting the immune tolerogenic response. The primary bacterial colonization of the intestine is the child's first immunity lesson.

\section{THE PROGRAMMING OF THE CIRCADIAN RHYTHM OF THE INFANTS THROUGH NATURAL FEEDING}

Human physiology and behaviour are driven by the circadian rhythm governed by the light-dark cy- 
cles and the energy metabolism, under the regulation of CNS $(18,19)$. The formation of the circadian rhythm in newborns and infants sets the rhythm for the wake/sleep periods and feeding demands. The composition of the maternal milk varies during the day. The concentration of gucocorticoids is three times higher in the morning milk than in the samples collected in the afternoon or in the evening, stimulating the activity, while the melatonin level is close to the limit of detection during the day, but during the night it can grow up to $280+/-34 \mathrm{pmol} / 1$ (melatonin being known as "the sleep hormone") $(20,21)$. This way the natural feeding works through chronosignals, helping the baby to differentiate between day and night periods in the first months of life.

\section{THE BEHAVIORAL PROGRAMMING OF THE BABY THROUGH TACTILE STIMULATION}

It is known that during the first years of life the baby displays a fascinating behaviour, which strengthens the emotional connection with the mother (father or close people). This complex system of interpersonal relationship is genetically programmed, its purpose is to ensure protection and it is common among all mammal babies. Known as attachment theory (22), it objectifies the young child's need for protection, calmness and the provision of the food intake. The attachment behaviour strongly manifests during alarm situations accompanied by emotional stress.

\section{THE PROGRAMMING OF STRESS RESPONSE}

Under experimental conditions (in rodents) it was found that the careful nursing of the babies through the maternal tactile contact is responsible for a moderate stress response (as compared to the babies deprived of maternal care) in the next stages of life $(23,24)$. Stress response involves a series of changes of the hypothalamic-pituitary-adrenal axis (HPA) expressed by the increase of $\mathrm{ACTH}$, of cortisol, of catecholamines etc. In children, too, it was found that there is a connection between physical contact, the amount of care and the range of stress response, proven by the fact that the careful maternal nourishing diminishes the intensity of reactivity to stressful factors of the environment. In these situations, at the molecular level, the increase of GR (glucocorticoid receptor) gene in the hippocampus has been found, followed by the decrease in the stress response of the HPA axis, change that is epigenetically transmitted to the later stages of age, too (24) (25). Oberlander et al (26) have looked into the relation between the maternal depressed/anxious behaviour in the third trimester of pregnancy and the increase of the degree of methylation of the cellular receptor gene for the glucocorticoids (GRG) followed by the increase of cortisol levels at the age of 3 months according to saliva testing. In the case of naturally fed 5-month-old nurslings, the decrease of methylation degree of GR gene and of cortisol reactivity was found, that is the natural feeding contributes to the physiological regulation of behaviour (27). The infant's crying (especially over extended periods) reflects the baby's stress and discomfort and represents a part of the emergency system in the infant-parent communication $(28,29)$. The presence of high-pitched crying (over $1 \mathrm{kHz}$ ) was linked to a weak voice control, to the deficient stress response regulation and may be an indicator of neurobehavioral integrity in the context of the change in expression of GR gene (29). It is possible that the epigenetic changes according to the methylation degree of GR gene represent a key factor in stress response, as some studies suggest $(25,30)$.

Due to the fact that glucocorticoids freely diffuse through the cell membrane it is important that there is another regulatory mechanism which would limit their access from the mother into the fetal circulation, avoiding the excessive gene expression. Under physiological conditions there is a glucocorticoid gradient of 1001000 times higher in maternal circulation compared to the fetal circulation. The deficiencies in maternal diet produce the decrease in activity of the placental enzyme 11 6-hydroxysteroid-dehidrogenase (116 HSD2). Under standard conditions this transforms the active glucocorticoids into forms without physiological activity, thus regulating the acces of maternal corticosterone to the fetus. If the placental barrier is not fully functional, the excessive maternal glucocorticoid transit stimulates the HPA fetal axis, with later somatic and behaviour changes (anxiety, stress response, $A H$ ) (44).

\section{THE PARENTAL CONFLICT IN FETAL PROGRAMMING}

The fetal development is controlled by the mother functional unit, placenta and fetus. Apparently paradoxical, the development of the fetus is determined by the contradictory interaction between maternal and paternal genes in the conflict named the genome war. The antagonistic effects are determined by the imprinted genes (which come from only one parent) which originate in the ovule or sperm. In this case, 


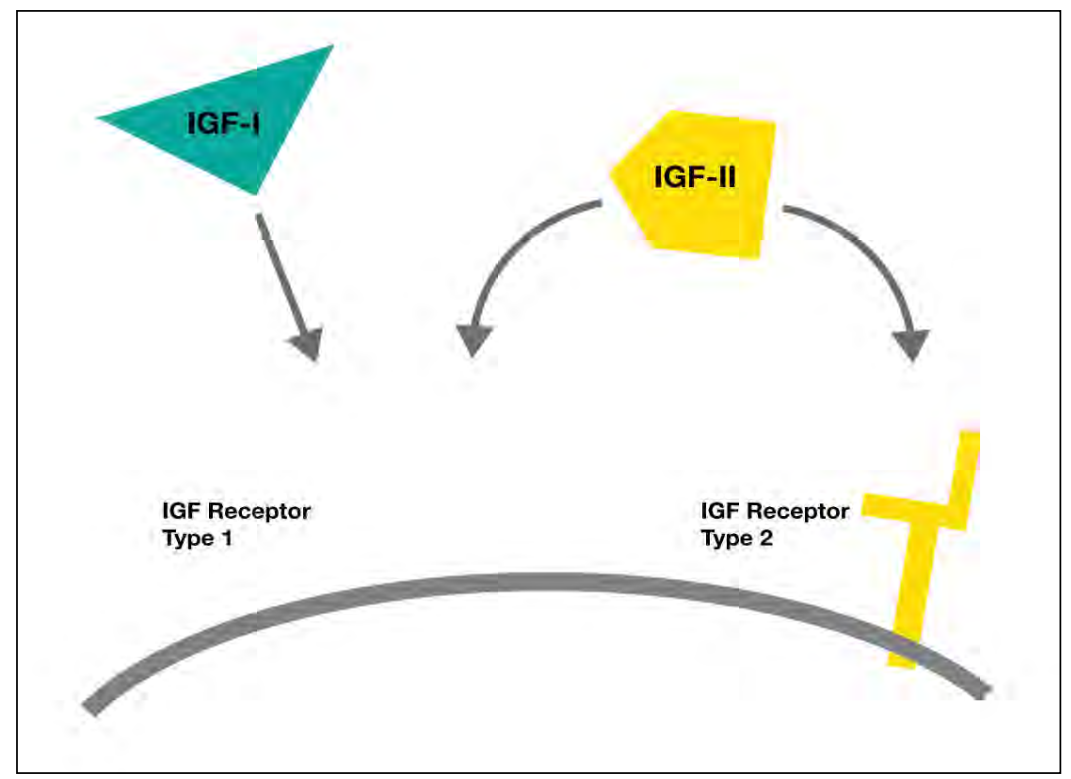

FIGURE 1. The control of placental $11 \beta$ hydroxysteroid dehydrogenase over the maternal glucocorticoid flow. It is important to note that dexamethazone diffuses freely in the placental space

some maternal genes can be expressed and the paternal ones completely inhibited or vice versa, some of the paternal genes can be active at the expense of the maternal ones.

\section{WAR OF THE SEXES}

The mother "is interested" in her survival, the conservation of the substrates and the diminishing of fetal weight, she transmits genes which limit fetal growth. The father, "interested in" increasing the fetal growth, fetal survival, higher birth weight, transmits paternal genes such as IGF-2. The factors IGF-1 and IGF-2 stimulate growth, acting upon the IGF-1r receptor. The second type of receptor, whose gene is of exclusive maternal provenance, IGF-2r, opposes growth by trapping and degradating of IGF-2 $(31,32)$.

\section{IS THERE A CHILD-MOTHER PROGRAMMING?}

The first opinions on the complex connection between mother and fetus date from 1993, when Haig (34) expressed the opinion that fetal genes increase the nutrient transfer towards the fetal metabolism, while the maternal ones limit the excess of their transit. Although this opinion may be considered excessive, one should take into consideration the effects of vascular and endocrine changes produced by the fetus on the maternal organism.
The fetal regulation of maternal homeostasis takes place on several levels:

- Vascular - During the first stages of intrauterine development the trophoblasts (marginal cells of the blastocyst) migrate to the maternal uterine epithelium and transform the endometrial spiral arteries into wide veins with low resistance. This way, the uteroplacental blood flow reaches $25 \%$ of the cardiac output.

- Endocrine-During pregnancy the placenta becomes an important endocrine organ by producing estrogens, progesterone, chorionic gonadotropin (hCG), placental lactogen (hPL) and derivates of the growth hormone (IGF1) (IGF2) (45).

The physiological pregnancy is accompanied by insulin resistance as a physiological adapation of the mother to provide an adequate carbohydrate intake for the fetus in rapid growth (35). The hormones produced by the placenta regulate the intake, the absorbtion, the use and the transfer of maternal nutrients to the fetus (36), at the same time, being at the origin of insulin resistance and, possibly, of gestational diabetes. The bidirectional exchange of live cells between mother and fetus has been highlighted in different studies, but the functions of fetal cells in the maternal tissues are not clearly defined (38-40). Some of the cells of the fetus transit the placenta even from the first weeks of the first trimester; feto-maternal cell transfer probably takes place in all of pregnancies (39). 


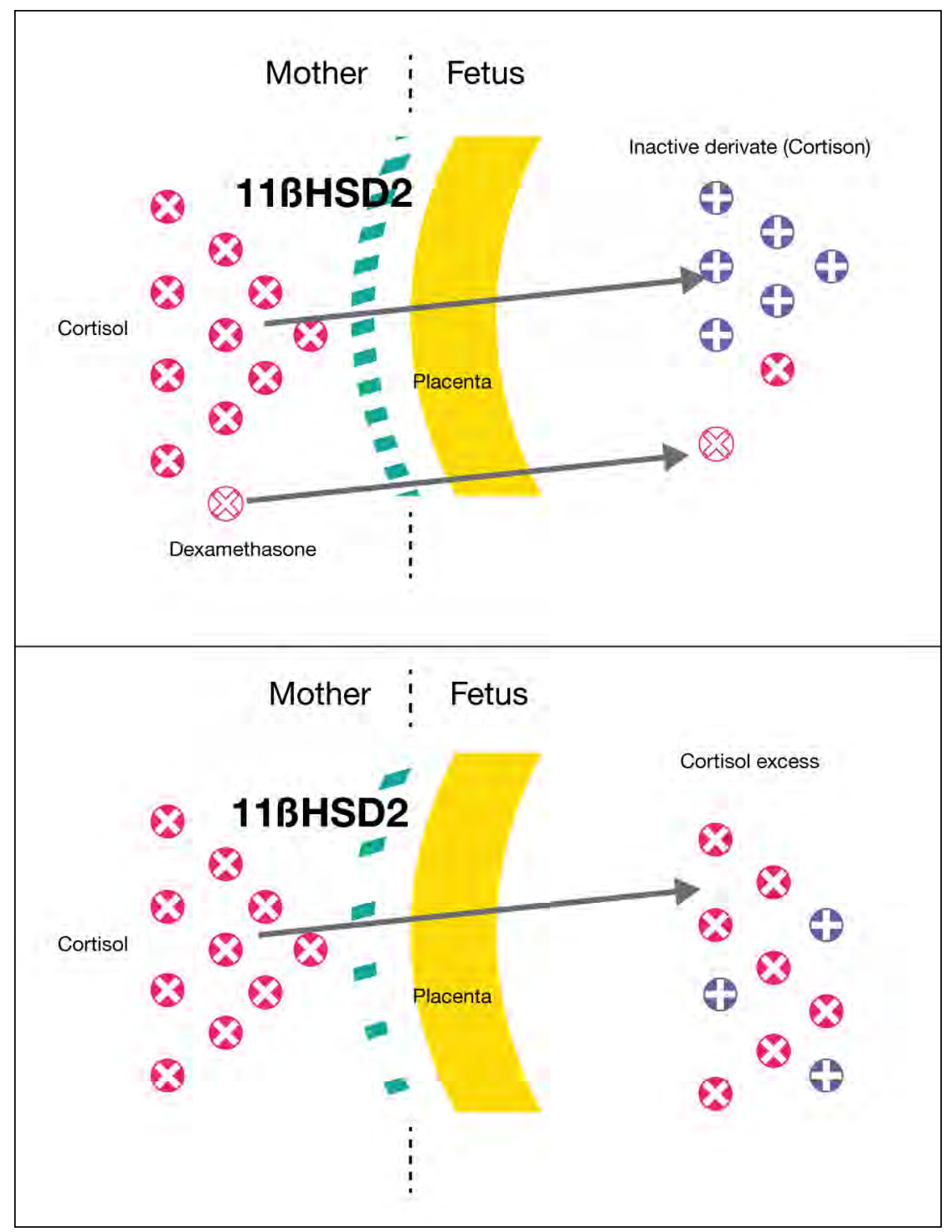

FIGURE 2. The interaction between IGF-1, IGF-2 and their receptors in the regulation of fetal growth in the experimental model in rodents; IGF-1 and IGF-2 stimulate the intrauterine growth, acting upon the receptor IGF-1r. The second type of receptor, IGF-2r, opposes growth by degradation of IGF-2 (33)

TABLE 3. Mother-child relation during the pregnancy and after. The theory of cooperation and conflict (the feto-maternal negotiation) can clarify the role of the microchimerism of the fetal cells in the mother's health $(38,41)$

\begin{tabular}{|l|l|l|}
\hline $\begin{array}{l}\text { The presence of } \\
\text { fetal cells }\end{array}$ & Baby's interest & Mother's interest \\
\hline Brain & $\begin{array}{l}\text { The manipulation of the parental neuroendocrine } \\
\text { system (oxytocin, prolactin) for nutrition and } \\
\text { strengthening the affection towards the baby }\end{array}$ & $\begin{array}{l}\text { The presence of fetal paternal** DNA cells in the brain } \\
\text { many years after birth of a son; integration in the neuronal } \\
\text { circuits. Role in differentiation of neurons }\end{array}$ \\
\hline Thyroid & The increase of heat production & $\begin{array}{l}\text { The regulation of the heat production at a level which } \\
\text { permits the optimization of the use of resources at present } \\
\text { and for the future offsprings }\end{array}$ \\
\hline Breast & $\begin{array}{l}\text { The fetal cells which migrated at the breast } \\
\text { level increase the production of milk through } \\
\text { stimulation factors or the differentiation in } \\
\text { mammary cells }\end{array}$ & $\begin{array}{l}\text { The modulation of the milk production; granting the } \\
\text { resources at present and for the offsprings }\end{array}$ \\
\hline Immune system & $\begin{array}{l}\text { The induction of maternal tolerance } \\
\text { Avoiding detection and destruction by the } \\
\text { maternal immune system }\end{array}$ & $\begin{array}{l}\text { The tolerance of semi-allogeneic fetal material. The } \\
\text { elimination of fetal cells which emphasize the resource } \\
\text { transfer at a level above the optimal one }\end{array}$ \\
\hline
\end{tabular}




\section{FETO-MATERNAL MICROCHIMERISM}

Feto-maternal microchimerism (the presence of a small number of cells originating in a subject genetically different from the host) is characterised by the preservation of a number of fetal cells in the maternal tissues for a long time (decades) (40). Their transfer may start shortly after the implantation (38). The fetal cells circulate in the maternal body, they can colonise different tissues and can be found in different maternal tissues and organs (e.g. blood, bone marrow, brain, liver, tegument) (36). Their role was interpreted either as being in the child's interest, or in the interest of the mother.

Microchimerism involves all types of fetal cells and trophoblasts, but especially fetal stem cells (42). The presence of some stem-like cells in different cellular lines indicates their capacity to transform into

\section{REFERENCES}

1. Lacal I, Ventura R. Epigenetic Inheritance: Concepts, Mechanisms and Perspectives. Front Mol Neurosci. 2018;11:292.

2. Barker DJ. Fetal origins of coronary heart disease. BMJ. 1995; 311(6998):171-4

3. Barker DJ, Forsén T, Uutela A, Osmond C, Eriksson JG. Size at birth and resilience to effects of poor living conditions in adult life: Longitudinal study. BMJ. 2001 Dec 1;323(7324):1273-6.

4. Hales C, Barker D. The thrifty phenotype hypothesis. Br Med Bull, 2001; 60:5-20.

5. Delisle H Programming of chronic disease by impaired fetal nutrition. WHO/NHD/02.1/02.3.

6. Buhtta Z, Guerrant R, Nelson CA. Neurodevelopment, Nutrition, and Inflammation: The Evolving Global Child Health Landscape. Pediatrics. 2017 Apr;139(Suppl 1):S12-S22.

7. Boekelheide K, Blumberg B, Chapin R, Cote I Predicting Later-Life Outcomes of Early-Life Exposures. Environ Health Persp. 2012, 120(10):1353-1361.

8. Luke B, Hedinger M. Perinatal Epidemiology of Metabolic Syndrome Risk Factors, in Lipshultz, Messiah, Miller (Eds) Pediatric Metabolic Syndrome, Springer 2012.

9. Smith J, Cianflone K, Biron S et al. Effects of Maternal surgical weight loss in mothers on intergenerational transmission of obesity. J Clin Endocrinol Metab. 2009;94(11):4275-4283.

10. Perez PF, Doré J, Leclerc M, Levenez F, Benyacoub J, Serrant $P$, Segura-Roggero I, Schiffrin EJ, Donnet-Hughes A. Bacterial imprinting of the neonatal immune system: Lessons from maternal cells? Pediatrics. 2007 Mar;119(3):e724-32.

11. Mathias A, Pais B, Favre L, Benyacoub J, Corthésy B. Role of secretory IgA in the mucosal sensing of commensal bacteria. Gut Microbes. 2014;5(6):688-95.

12. Grindstaff J, Brodie E, Ketterson E. Immune function across generations: Integrating mechanisms and evolutionary process in Maternal antibody transmission. Proc R Soc Lond. 2003;270;2309-19.

13. M'Rabet L, Vos A, Boehm M et al. Breast-feeding and its role in early development of the immune system in infants: Consequences for health later in life. J Nutr. 2008;138(9):1782S-1790S.

14. Prakash S, Rodes I, Cousa-Charley M et al. Gut microbiota: Next frontier in understanding human health and development of biotherapeutics. Biologics: Targets and Therapy, 2001;5:71-86.

15. Romano-Keeler J, Weitkamp JH. Maternal influences on fetal microbial colonisation and immune development. Pediat Res. 2015;77(1-2):189-195. adult hematopoietic cells in all the lines (42), in endothelial cells, neurons, smooth muscle cells and cardiomyocytes (41). Their migration and their role in healing the lesions produced by the caesarean section by producing type I and III collagen and TGF- $\beta$ (43) have been proven. On the other hand, the microchimeric fetal cells, by their escaping from the maternal immune system, were involved in the pathogenesis of some cancers and some autoimmune diseases (e.g. SLE, scleroderma) $(38,41)$.

\section{CONCLUSION}

Despite all the contradictory aspects, it is obvious that the exchange of hormones, immunity, cells represents a bidirectional mother-child path of communication, which continues in other ways the entire life.

Conflict of interest: none declared Financial support: none declared

16. Dzidic M, Boix-Amoros A, Selma-Royo M, Mira A, Collado M. Gut Microbiota and Mucosal Immunity in the Neonate. Med Sci. 2018;6:56.

17. Torow N, Hornef M. The Neonatal Widow of Opportunity: Setting the Stage for Life-Long Host-Microbial Interaction and Immune Homeostasis. J Immunol, 2017;198:557-563.

18. Dibner C, Schibler U, Albrecht U. The Mamalian Circadian Timing System: Organization and Coordination of Central and Peripheral Clocks. Ann Rew Physiol. 2010;72(1):517-549.

19. Mendoza J Circadian clocks: setting time by food. J Neuroendocrinol. 2007;19(2):127-137.

20. Pundir S, Wall C, Mitchell $C$ et al. Variation of Human Milk Glucocorticoids over 24 hour Period. J Mammary Gland Biol Neopl, 2017; 22(1):85-92.

21. Illnerova H, Buresova M, Presl J. Melatonin rhytm in human milk. J Clin Endocrinol Metab. 1993;77(3):838-41.

22. Bretherton I. The Origins of Attachment Theory: John Bowlby and Mary Ainsworth. Developmental Psychol. 1992;28:759-75.

23. Caldji C, Tannenbaum B, Sharma A et al. Maternal care during infancy regulates the development of neural systems mediating the expression of fearfulness in the rat. Proc Natl Acad Sci USA, 1998; 95:5335-40.

24. Liu D, Diorio J, Tannenbaum B, Caldji C et al. Maternal Care, Hippocampal Glucocorticoid Receptors, and Hypothalamic-PituitaryAdrenal Responses to Stress. Science, 1997;277:1659-62.

25. Tyrka AR, Parade SH, Welch ES, Ridout KK1, Price LH, Marsit C, Philip NS, Carpenter LL. Methylation of the leukocyte glucocorticoid receptor gene promoter in adults: associations with early adversity and depressive, anxiety and substance-use disorders. Transl Psychiatry. 2016 Jul 5;6(7):e848.

26. Oberlander TF, Weinberg J, Papsdorf M, Grunau R, Misri S, Devlin AM. Prenatal exposure to maternal depression, neonatal methylation of human glucocorticoid receptor gene (NR3C1) and infant cortisol stress responses. Epigenetics. 2008;3(2):97-106.

27. Lester B, Conradt E, La Grasse L et al. Epigenetic Programming by Maternal Behavior in the Human Infant. Pediatrics, 2018;142(4): e20171890.

28. Zeifman D, St James-Roberts I. Parenting the Crying Infant. Curr Opin Psychol. 2017;15:149-54.

29. Sheinkopf SJ, Righi G, Marsit CJ, Lester BM. Methylation of the Glucocorticoid Receptor (NR3C1) in Placenta Is Associated with Infant Cry Acoustics. Front Behav Neurosci. 2016;10:100. 
30. Perroud N, Paoloni-Giacombino A, Prada P et al. Increased methylation of glucocorticoid receptor gene (NR3C1) in adults with a history of childhood maltreatment: A link with the severity and type of trauma. Transl Psychiatry 2011;1:e59.

31. Ong K, Kratzsch J, Kiess W et al. Size al birth and cord blood levels of insulin, insulin-like growth factor I (IGF-1), IGF-2, IGF-binding protein-1 (IGFBP-1), IGFBP-3, and the soluble IGF-II/mannose-6phosphate receptor in term human infants. The ALSPAC Study Team. Avon Longitudinal Study of Pregnancy and Childhood. J Clin Endocrinol Metab. 2000;85(11):4266-9.

32. Haig D. Paternal antagonism, relatedness asymmetries, and genomic imprinting. Proc Royal Soc London B, 1997;264:1657-62.

33. Hokken-Koelega A Overview of SGA - www.medscape com/ viewprogram/15701_pnt,2008.

34. Haig D. Genetic conflicts in human pregnancy. Q Rev Biol. 1993; 68(4):495-532.

35. Sonagra A, Biradar S, Dattatreya K, Murthy J Normal Pregnancy - a State of Insulin Resistance. J Clin Diagn Res. 2014; 8(11):CC01CC03.

36. Freemark M. Placental hormones and the control of fetal growth. Intern J Ped Endocrinol. 2015; Suppl 1:013.

37. Singh R, Hatt L, Ravn K et al. Fetal cells in maternal blood for prenatal diagnosis: A love story rekindled. Biomarkers Med. 2017;11:9.
38. Dawe GS, Tan XW, Xiao ZC. Cell migration from baby to mother. Cell Adh Migr. 2007 Jan-Mar;1(1):19-27.

39. Sunami R, Komoro M, Yuminamochi T, Hirata S. Fetal cell microchimerism develops through the migration of fetus-derived cells to the maternal organs early after implantation. J Reprod Immunol. 2010;84(1):117-23.

40. Bianchi D, Zickwolf G, Weil G et al. Male fetal progenitor cells persist in maternal blood for as long as 27 years postpartum. Proc Natl Acad Sci USA 1996;93(2):705-8.

41. Boddy A, Fortunato A, Sayres M, Aktipis A. Fetal microchimerism and maternal health: A review and evolutionary analysis of cooperation and conflict beyond the womb. Bioessays, 2015;37:1106-18.

42. van der Giessen J, Huang VW, van der Woude CJ, Fuhler GM. Modulatory Effects of Pregnancy on Inflammatory Bowel Disease. Clin Transl Gastroenterol. 2019 Mar;10(3):e00009.

43. Mahmood U, O'Donoghue K. Microchimeric fetal cells play a role in maternal wound healing after pregnancy. Chimerism, 2014;5(2):40-52.

44. Langley-Evans S. Nutrition: A Lifespan Approach. Wiley-Blackwell, 2009.

45. Murphy VE, Smith R, Giles WB, Clifton VL. Endocrine regulation of human fetal growth: The role of the mother, placenta, and fetus. Endocr Rev. 2006;27(2):141-69. 